\title{
A meta-level analysis of major trends in environmental health risk governance
}

\author{
Hens A.C. Runhaar , P.P.J. Driessen , L. van Bree \& J.P. van der Sluijs
}

To cite this article: Hens A.C. Runhaar , P.P.J. Driessen , L. van Bree \& J.P. van der Sluijs (2010) A meta-level analysis of major trends in environmental health risk governance, Journal of Risk Research, 13:3, 319-335, DOI: 10.1080/13669870903139070

To link to this article: https://doi.org/10.1080/13669870903139070

曲 Published online: 30 Mar 2010.

Submit your article to this journal $\pi$

Llll Article views: 292

Q View related articles $\square$

Citing articles: 10 View citing articles $\longleftarrow$ 


\title{
A meta-level analysis of major trends in environmental health risk governance
}

\author{
Hens A.C. Runhaar ${ }^{a *}$, P.P.J. Driessen ${ }^{a}$, L. van Bree ${ }^{b}$ and J.P. van der Sluijs ${ }^{a}$ \\ ${ }^{a}$ Copernicus Institute for Sustainable Development and Innovation, Utrecht University, \\ Utrecht, The Netherlands; ${ }^{b}$ Netherlands Environmental Assessment Agency, Bilthoven, \\ The Netherlands
}

(Received 7 October 2008; final version received 24 June 2009)

\begin{abstract}
Internationally but also within countries, large differences exist regarding how environmental health risks (EHRs) are governed. Despite these differences, at a meta-level some general trends can be discerned that may point to a convergence of EHR governance regimes. One, EHR governance regimes are increasingly taking into account cost-benefit considerations, sectoral goals outside the health risk domain, public concerns and stakeholder interests in early stages of decisionmaking. Two, EHR objectives are increasingly integrated in other, sectoral policies such as land use planning. Three, an increased differentiation of EHR standards is observed (partly as a consequence of the former characteristic). Still little systematic empirical research has been conducted on the dynamics in EHR governance regimes and their causes, on what EHR governance regimes have produced in terms of (perceived) risk reduction and on how these results can be explained. This paper proposes a systematic framework for analysing, explaining and evaluating shifts in EHR governance regimes. The framework in turn is applied to examine and understand the shift towards more integrated and differentiated EHR governance regimes.
\end{abstract}

Keywords: risk governance; environmental health risks; integration; differentiation; participation

\section{Introduction}

Risks to human health in part stem from our physical environment. These so-called environmental health risks (EHRs) are addressed by public and private policies that aim at avoiding or reducing environmental exposures or by mitigating the effects of exposure to these risks. Framing of risks, standards, principles for standard-setting or instruments implemented for reaching these standards differ strongly internationally (e.g. Harrami, Postgård, and Strömgren 2009a; Harrami et al. 2009b; see also Hood, Rothstein, and Baldwin 2004; NEAA 2009; O'Riordan 1985). In addition, national governments often have no consistent frameworks for dealing with similar types of risks in different domains, in terms of scientifically proven severity, public concern or cost-effectiveness. This inconsistency is both criticised by some scientists (e.g. Renn 2008a) and felt as being problematic by some governments (e.g. VROM 2004) and stakeholders.

*Corresponding author. Email: h.runhaar@geo.uu.nl 
Despite differences between the ways in which individual EHRs are governed in specific countries, at a meta-level some generic shifts in EHR governance can be discerned. In a survey conducted in 2007 in 10 European countries, the USA and Australia (Soer et al. 2009), these shifts are summarised as a turn from 'traditional', specialised approaches to more integrated and differentiated approaches to EHR governance. On the one hand there is an increased integration of (1) cost-benefit and other considerations; (2) the public and other stakeholders; and (3) EHR objectives in other sectoral policies, whereas on the other hand an increased differentiation of EHR standards (partly as a consequence of the former characteristic) is observed.

To date, only limited comparative empirical research has been conducted on EHR governance, dynamics in EHR governance and experiences with different forms of EHR governance (Hood, Rothstein, and Baldwin 2004), in particular at a meta-level (i.e. over time and covering health risks in general as dealt with in a large number of countries). The few publications in this area are primarily concerned with classifying EHR governance regimes and elaborating on the appropriateness of specific regimes in distinct contexts (see Section 2) (Hood, Rothstein, and Baldwin 2004; O'Riordan 1985; Renn 2006). Yet, these papers are mainly conceptual or normative in nature; empirical analyses and evaluations in this area are scarce.

As there is no generally accepted framework for characterising, analysing and evaluating (shifts in) EHR governance regimes, in this paper we first elaborate upon an appropriate framework for empirical analysis. Then we characterise, explain and evaluate the shifts in EHR governance at a meta-level as outlined above and reported by Soer et al. (2009) by means of our analytical framework. We conclude the paper with some suggestions for further research in this area.

\section{EHR governance}

\subsection{EHRs}

Although the concept of 'risk' is subject to many debates, in this paper we will employ a definition that is generally accepted: risk is 'an uncertain (generally adverse) consequence of an event or an activity with respect to something that humans value' (Bunting 2008, 35). The two main components of risk are the probability of an event and its consequences for health, environment and goods (e.g. Neumann and Politser 1992). In this paper the focus is on EHRs. These are risks associated with exposure to environmental factors. Various classifications of EHRs have been suggested. For an example see Figure 1. Distinction can be made between health risks related to natural events (e.g. floods, earthquakes) and man-induced EHRs (e.g. by emissions of toxic substances or production of noise). In this paper we focus on the latter type of EHRs, as we expect that for these type of risks there are more opportunities to influence them (in the case of natural events EHR management will mainly be focused on adaptation of adverse health effects and less with fundamentally addressing their uncontrollable causes). We acknowledge that the distinction between natural and man-induced risks is somewhat arbitrary; the chance and magnitude of for instance floods in part depends on for example how rivers are managed. Other classifications of EHRs are based on certainty of knowledge available or on values on the probability and consequences of risks (e.g. low probability-high impact singular event risks such as nuclear power plant accidents versus more continuous risks such as noise nuisance and air pollution). 


\begin{tabular}{|r|r|}
\hline Physical Agents \\
\hline lonising radiation \\
$\circ$ Non-ionising radiation \\
$\circ$ Noise (industrial, leisure, etc.) \\
$\circ$ Kinetic energy (explosion, collapse, etc.) \\
$\circ$ Temperature (fire, overheating, overcooling) \\
\hline Chemical Agents \\
\hline Biological Agents \\
$\circ$ Toxic substances (thresholds) \\
$\circ$ Environmental pollutants \\
$\circ$ Compound mixtures \\
\hline$\circ$ Fungi and algae \\
$\circ$ Viruses \\
$\circ$ Genetically modified organisms \\
$\circ$ Other pathogens \\
\hline Natural Forces \\
\hline$\circ$ Wind \\
$\circ$ Earthquakes \\
$\circ$ Volcanic activities \\
$\circ$ Drought \\
$\circ$ Flood \\
\hline & (Wild) fire \\
\hline & Avalanche \\
\hline
\end{tabular}

Figure 1. Typology of EHRs (with examples).

Source: Renn $(2006,20)$.

EHRs form a dynamic field; over time we see new types of EHRs emerging. Today, some new EHRs are related to (human induced) global environmental change. For instance, climate change is expected to result in a higher risk of floods in particular countries (Johnson, Tunstall, and Penning-Rowsell 2005). Other EHRs are associated with 'bio invasions': species entering environments new to them with sometimes negative consequences for human health (Mack et al. 2000; McMichael and Beaglehole 2000; Stohlgren and Schnase 2006). Bio invasions have their origin in climate change but also in intensified food production and in globalisation-related processes like trade, transport and migration. At other scale levels, EHRs that have been considered a potential hazard or have become manifest to some extent are for instance health risks related to nanoparticles (Handy, Owen, and Valsami-Jones 2008) or to radiation from mobile telephone base stations (Annesi-Maesano et al. 2007; Valberg, van Deventer, and Repacholi 2007). Risks from radiation are contested; public and scientific risk perceptions diverge heavily.

\subsection{EHR governance regimes}

In this paper we adopt the definition of Hood, Rothstein, and Baldwin $(2004,9)$ who define EHR governance regimes as 'the complex of institutional geography, rules, practice, and animating ideas that are associated with the regulation of a particular risk 
or hazard'. This definition is broad enough to include ways in which particular risks are framed, formal policies on EHR governance but also its implementation in practice, and formal and informal rules and organisations that are involved in EHR governance.

In the risk literature only limited publications are available on the characterisation and classification of risk regimes (Hood, Rothstein, and Baldwin 2004). The few publications available contain common but sometimes also different aspects of such regimes. O'Riordan (1985; who speaks of 'styles of risk regulation') characterises risk regimes primarily in the way in which decision-making is organised (top-down, interactive, etc.) and the extent to which consensus among stakeholders is present or possible. Hood, Rothstein, and Baldwin (2004) consider risk governance regimes as systems with two main dimensions: 'basic control system components', including the typical ways of gathering information, risk assessment, standard-setting and policy instruments; and the 'instrumental' and 'institutional' elements of regulatory regimes, including contextual variables (the different types of risks at hand, the nature of public preferences and attitudes over risk and the ways in which stakeholders are organised) and the regime variables (the policy setting, the configuration of state and other organisations directly engaged in risk regulation and their attitudes, belief and 'operating conventions'). On the basis of these dimensions and variables, Hood, Rothstein, and Baldwin (2004) analytically distinguish between nine types of risk governance regimes. The International Risk Governance Council (IRGC) takes a more normative approach, stating that risk governance is more than the three conventional elements of risk analysis, risk management and risk communication - these elements should be supplemented with elements from 'good governance' such as stakeholder involvement and political accountability (Renn 2008b). The IRGC in addition advocates a framework that classifies risk governance regimes in terms of, among other things, certainty of knowledge and contentedness (Bunting 2008; Renn 2006, 2008c; see Figure 2). ${ }^{1}$ The IRGC framework also shows which management strategies, risk reduction instruments and stakeholder participation methods apply in distinct cases. The aim of this proposed framework is, among other things, to enhance cost-effectiveness, equal distribution of risks and benefits and consistency in risk governance.

Another important element of risk governance regimes as found in the literature is the way in which an EHR is 'framed' or perceived by actors (e.g. Renn 2008b; Tukker 2002). Different conceptions of risks and associated ideas on how risks should be managed result in different governance regimes. Rayner and Cantor (1987) discuss four different 'institutional cultures' that may underlie risk governance and that reflect distinct worldviews, based on particular principles of social justice and perceived economic interests. Commonly found principles for EHR governance include an equal protection for all, achieving the greatest increase in overall public health at the lowest cost or the precautionary principle (see, for instance, De Hollander and Hanemaaijer 2003).

In conclusion we can state that there is no such thing as a generally accepted framework for characterising and classifying risk governance regimes - and distinguishing it from its context. Nevertheless the literature review has yielded some relevant generic elements of risk governance regimes that can be classified as follows:

- Objectives of risk governance regimes, referring to risk reduction standards for EHRs (e.g. maximum exposure levels) and underlying principles (e.g. equal protection for all or as low as reasonably practicable); 


\begin{tabular}{|c|c|c|c|c|}
\hline \multicolumn{2}{|c|}{$\begin{array}{l}\text { Knowledge } \\
\text { Characterisation }\end{array}$} & $\begin{array}{l}\text { Management } \\
\text { Strategy }\end{array}$ & Appropriate Instruments & $\begin{array}{l}\text { Stakeholder } \\
\text { Participation }\end{array}$ \\
\hline \multicolumn{2}{|c|}{$\begin{array}{l}1 \text { 'Simple' risk } \\
\text { problems }\end{array}$} & $\begin{array}{l}\text { Routine-based: } \\
\text { (risk evaluation) } \\
\text { (risk reduction) }\end{array}$ & $\begin{array}{l}\rightarrow \text { Applying 'traditional' decision-making } \\
\text { - } \text { Risk-benefit analysis } \\
\text { - } \text { Risk-risk trade-offs } \\
\text { - } \quad \text { Trial and error } \\
\text { - } \quad \text { Technical standards } \\
\text { - Economic incentives } \\
\text { - Education, labelling, information } \\
\text { - } \quad \text { Voluntary agreements }\end{array}$ & $\begin{array}{l}\text { Instrumental } \\
\text { discourse }\end{array}$ \\
\hline & \multirow[t]{2}{*}{$\begin{array}{l}\text { Complexity- } \\
\text { induced risk } \\
\text { problems }\end{array}$} & $\begin{array}{l}\text { Risk-informed: } \\
\text { (risk agent and } \\
\text { causal chain) }\end{array}$ & $\begin{array}{l}\rightarrow \text { Setting the 'facts' straight } \\
\text { - } \quad \text { Expert consensus seeking tools: } \\
\text { - Delphi or consensus conferencing } \\
\text { - meta analysis } \\
\text { - scenario construction, etc. } \\
\text { - } \text { Results fed into routine operation }\end{array}$ & $\begin{array}{l}\text { Epistemological } \\
\text { discourse }\end{array}$ \\
\hline & & $\begin{array}{l}\text { Robustness- } \\
\text { focussed: } \\
\text { (risk absorbing } \\
\text { system) }\end{array}$ & $\begin{array}{l}\rightarrow \text { Improving buffer capacity of risk target } \\
\text { through: } \\
-\quad \text { Additional safety factors } \\
\text { - } \quad \text { redundancy and diversity in designing } \\
\text { safety devices } \\
\text { - } \quad \text { improving coping capacity } \\
-\quad \text { establishing high reliability organisa- } \\
\text { tions }\end{array}$ & \\
\hline & \multirow[t]{2}{*}{$\begin{array}{l}\text { Uncertainty- } \\
\text { induced risk } \\
\text { problems }\end{array}$} & $\begin{array}{l}\text { Precaution- } \\
\text { based: } \\
\text { (risk agent) }\end{array}$ & $\begin{array}{l}\rightarrow \text { Using hazard characteristics such as } \\
\text { persistence, ubiquity, etc. as proxies } \\
\text { for risk estimates } \\
\text { Tools include: } \\
\text { - Containment } \\
\text { - } \text { ALARA (as low as reasonably achiev- } \\
\text { able) } \\
\text { - BACT (best available control technol- } \\
\text { ogy), etc. }\end{array}$ & $\begin{array}{l}\text { Reflective } \\
\text { discourse }\end{array}$ \\
\hline & & $\begin{array}{l}\text { Resilience- } \\
\text { focussed: } \\
\text { (risk absorbing } \\
\text { system) }\end{array}$ & $\begin{array}{l}\rightarrow \text { Improving capability to cope with sur- } \\
\text { prises } \\
\text { - } \text { Diversity of means to accomplish de- } \\
\text { sired benefits } \\
\text { - } \quad \text { Avoiding high vulnerability } \\
\text { - } \\
\text { - }\end{array}$ & \\
\hline 4 & $\begin{array}{l}\text { Ambiguity- } \\
\text { induced risk } \\
\text { problems }\end{array}$ & $\begin{array}{l}\text { Discourse- } \\
\text { based: }\end{array}$ & $\begin{array}{l}\rightarrow \text { Application of conflict resolution } \\
\text { methods for reaching consensus or } \\
\text { tolerance for risk evaluation results and } \\
\text { management option selection } \\
\text { - Integration of stakeholder involvement } \\
\text { in reaching closure } \\
\text { - Emphasis on communication and } \\
\text { social discourse }\end{array}$ & $\begin{array}{l}\text { Participative } \\
\text { discourse }\end{array}$ \\
\hline
\end{tabular}

Figure 2. Suggested approach for characterising and managing risks by the International Risk Governance Council.

Source: Renn $(2006,16)$.

- Knowledge sources in decision-making on EHR standards. Particularly relevant here is the role of science vis-à-vis other knowledge sources such as lay knowledge and perceptions;

- Management instruments employed to realise the above risk standards, such as permits, emission trading and the prescription of use of best available techniques; 
- Actors: the plurality and diversity of actors responsible for and directly involved in decision-making, the moment of their involvement, and their role in the implementation of EHR strategies;

- Context including culture, the public and other stakeholders and their characteristics and configurations, and the institutional context (organisation of the state, policies, legislation, informal rules, etc.).

An interesting question is how these elements are related and how this can explain the differences in specific configuration of EHR governance regimes as found in practice. The literature suggests that the risk governance context provides some important explanations. For instance, from the literature we know that risk governance is influenced by powerful stakeholders. Hood, Rothstein, and Baldwin (2004) and Loewenberg (2006) for instance describe cases where lobbies from industry successfully resulted in postponing risk management or in lowering standards for risk reduction, whereas Vos, Ceukelaire, and Stuyft (2006) show how donors and international financial institutes provoke changes in risk governance. Calamities are another often-mentioned source of dynamics in EHR governance regimes (e.g. Johnson, Tunstall, and PenningRowsell 2005; Wiering and Arts 2006). ${ }^{2}$ Langford et al. (2000) discuss the importance of public perceptions on risk governance. Other factors affecting governance regime dynamics are found at the international level (and often contribute to a convergence of national risk governance regimes), such as EU legislation but also knowledge sharing and dissemination through bodies such as the IRGC, and at the domestic level (and often resulting in a divergence of governance regimes) such as dominant national governance styles and path dependencies as a consequence of routines in risk governance.

\subsection{Evaluating EHR governance regime performance}

Although many criteria can be employed for assessing the performance of EHR governance regimes (see for instance those employed by the IRGC in Section 2.2), one of the basic criteria is the extent to which they succeed in reducing EHRs to levels that are acceptable to decision-makers, the public, scientists and other stakeholders. At least two interrelated dimensions are relevant here. The first is the speed with which governance regimes emerge for EHRs identified and accepted on political agendas. The second is the outcome in terms of (perceived) risk reduction and its evaluation by relevant actors.

Yet, it is also interesting to move beyond the level of individual EHRs, for example by looking at how EHR regimes impact upon other EHRs. Relevant in this light is the concept of 'risk migration': the situation where one risk is reduced but another one created or enhanced. A (classical) example concerns polybrominated diphenyl ethers (PBDEs) based flame-retardant compounds that accumulated in the environment and in humans and in particular caused societal anxiety when they were found in breast milk (Alcock and Busby 2006).

\subsection{Towards a framework for analysing and evaluating EHR governance regimes and their dynamics}

In Section 2.2 and 2.3 we discussed various elements of EHR governance regimes and factors in their context that influence dynamics in EHR governance. Figure 3 brings 
together these elements and factors, which are organised at four levels: the EHRs as objects of EHR governance, governance regimes, regime outcomes and the broader context in which EHR governance takes place. Arrows indicate the types of relationships between the elements that we expect to find in empirical analysis. Feedback loops from EHR governance regimes and their outcomes to their context are possible, but for the sake of this paper ignored in the figure. The framework is meant as an interpretative framework: we do not specify a priori hypotheses between its variables, but instead propose to examine their relations and those with variables that are not yet known in a more qualitative way.

\section{Meta-level dynamics in EHR governance: an assessment}

Rather than predefining distinct configurations of EHR governance regimes (cf. Hood, Rothstein, and Baldwin 2004) and analyse and evaluate these, we suggest taking the elements from the analytical framework presented above to identify distinct EHR governance regimes and developments in these regimes from observations in practice. In this section we will use our analytical framework in order to characterise, understand and evaluate shifts in EHR governance regimes at meta-level, i.e. at the level of how at a national level EHRs are governed and how that has changed over time.

Our empirical basis is a survey conducted in 2007 (Soer et al. 2009) in which trends in EHR governance in the Netherlands were compared with those in nine European countries, the USA and Australia. The survey was based on an analysis of official documents and a survey among EHR practitioners (working for environmental

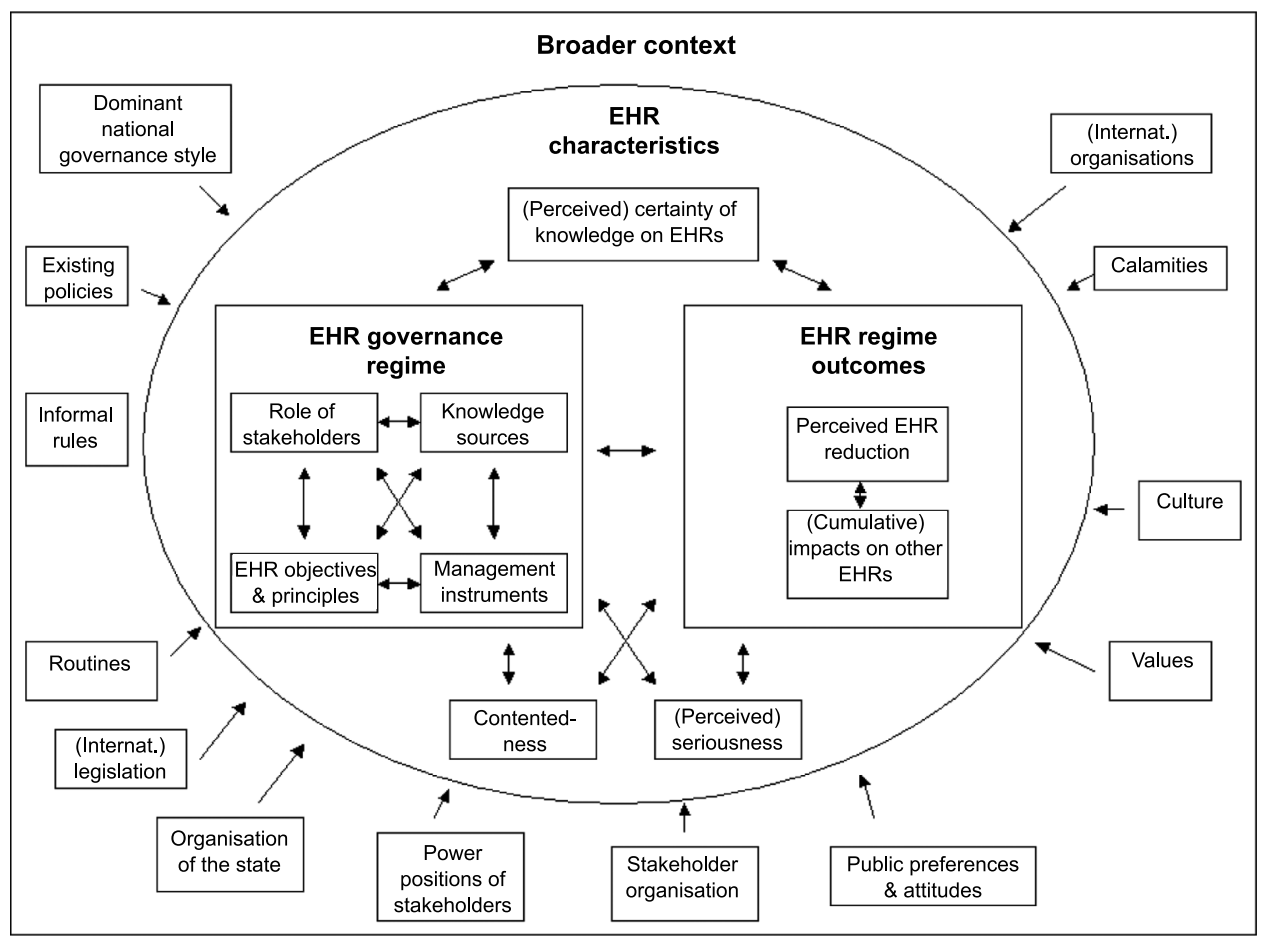

Figure 3. Framework for characterising, explaining and evaluating EHR governance regimes. (Source: Authors). 
protection agencies, health departments, etc.). The authors observe governance shifts that they summarise as a turn from a 'traditional', specialised approach to a more integrated and differentiated approach. How can this trend be characterised, understood and evaluated from the perspective of our framework? Below we will first describe and evaluate the way in which EHRs traditionally have been governed and then try to explain shifts and make (primarily) an ex ante evaluation of them. We realise that what we label as the traditional EHR governance regime is a simplification. The distinction between the traditional EHR governance regime and more integrated and differentiated EHR governance regimes namely is a dichotomy that does not completely reflect reality as it ignores hybrid governance regimes. However, the dichotomy allows us to identify some recent shifts in EHR governance and to illustrate the value of our framework.

\section{1. 'Specialised' EHR governance regimes}

\subsubsection{Characterising EHR governance regimes}

The traditional way of dealing with EHRs as could be observed in many Western countries as from the Industrial Revolution (but in particular after the Second World War) can be summarised as follows (e.g. Fiorino 1990; Heriard-Dubreuil 2001; O’Riordan 1985; Sunstein 2002):

- Regarding EHR objectives: EHRs are dealt with on an individual basis. Where possible quantified standards are formulated that are generic, i.e. apply to all of the situations specified. This results in detailed, quantified standards, which is one of the reasons why this approach is often considered 'technocratic'. Compensation of health risks geographically or between groups of people (either concerning one specific risk type or between different risk types) usually is not allowed. Objectives are based primarily on estimated health impacts, preferably based on scientific risk assessments. Cost-benefit and other considerations usually do not play a major role in an early stage of EHR governance, i.e. in the definition of standards.

- Regarding knowledge sources: scientists are the logical providers of knowledge on the nature and severity of EHRs and the exposure levels at which these health risks occur.

- Regarding management instruments: a linear approach to EHR governance is taken: implementation and the selection of instruments (of which legislation and licenses are typical) follows after risk assessment and standard-setting and does not play a large role in earlier stages of EHR policy.

- Regarding actors: usually government agencies set standards in hierarchical ways. (Formal) public participation is limited or absent. Informal influences by stakeholder groups however do exist (see Section 2.2).

Today this approach, which can be called 'specialised' due to its focus on individual EHRs from a health perspective, can still be observed worldwide. In Europe, for instance, this approach is visible in EU Directives regulating EHRs.

\subsubsection{Explaining 'specialised' EHR regimes}

The EHR governance regime context provides several explanations for what we label 'specialised' regimes. The technocratic and hierarchical character of EHR regimes 
reflects wider ideas on the role of governments in society, which were dominant in Western, liberal societies until some two decades ago. (Central) governments were considered to have a strong and leading role in addressing social problems and there was much faith in the contribution that science could have in enhancing the effectiveness and efficiency of government policy (Fischer 1997; van de Riet 2003). This has become institutionalised in very specialised (and growing) bureaucracies and an important role of (institutionalised) science-based knowledge providers ('policy analysis').

\subsubsection{EHR governance outcomes}

The traditional, 'specialised' approach has resulted in the successful reduction of various health risks. For instance, in the Netherlands air and water quality improvements were realised and smog levels were reduced dramatically, while the noise problem was stabilised (Keijzers 2000). A similar picture emerges if we take a European perspective for air and water quality (e.g. EEA 2003, 2007, regarding air and water quality). Other EHRs that have successfully been reduced include those associated with chemical substances like benzene, dioxins and pesticides (NEAA 2009).

Yet, the traditional approach to EHRs also encountered several (and interrelated) problems that are related to characteristics of the EHR governance regime configuration. These are (1) a lack of scientific evidence, seriously hampering EHRs governance; (2) too little attention paid to cost and cost-effectiveness considerations; (3) EHR objectives that do not reflect public and stakeholder concerns; (4) a lack of incentives to reduce EHRs beyond legal minimum norms; (5) inadequate management of health risks at other levels than that of specific individual EHRs; and (6) a lack of principles to decide which actor should be responsible for EHR governance.

3.1.3.1. Problem 1: A lack of scientific knowledge. In specialised EHR governance regimes, scientific knowledge on health effects plays an important role in EHR objectives and standards. Yet such regimes can only be operational when relevant scientific knowledge is available - something which is not always the case (Health Council of the Netherlands 1995; Open University 1998; US EPA 2004; VROM 2004). This problem is particularly salient in assessing possible long-term adverse effects of new technologies where no cohort studies or other past experience can be available yet, such as consequences of chronic exposure to electromagnetic fields from UMTS technology or chronic exposure to nanoparticles in consumer products (cosmetics, washing powder, etc.). From asbestos, for instance, we now know that there can be a delay between exposure and effect of 10 to 40 years. For both UMTS technology and nanoparticles part of the risk management strategy is to intensify the studies focusing on health effects from long-term exposure.

\subsubsection{Problem 2: Too little attention paid to cost-benefit/cost-effectiveness con-} siderations. EHR objectives in specialised regimes are typically based on scientific evidence of health effects. Cost-benefit considerations usually are not of primary importance. Regarding some EHRs this has resulted in what are perceived as excessive costs of meeting EHR standards (e.g. Health Council of the Netherlands 1995; NEAA 2009). An example is soil quality; in many Western countries, including for instance Denmark and the Netherlands, there are vast amounts of land polluted by industrial emissions that, given the wish to reduce a risk that might be relatively low, 
need to be cleaned up, but for which the huge costs are greatly disputed (Soer et al. 2009). Remarkably, in The Netherlands, parliament decided to actually spend considerable amounts of money for clean up, because of the public's opinion that soil contamination could form a certain risk and real estate values decreased when built on a contaminated spot. Another example is radon gas in buildings, causing lung cancer, and Legionella infections in medium warm water. At least in the Netherlands, the costs of reducing all of these risks are calculated as excessive compared to the magnitude of the risk avoided, and as a result this EHR is not a target in policy in the classical sense. However, there are agreements between (1) the government and the construction sector to use radon-low or radon-free materials to reduce exposure, and (2) (local) government and building owners with protective guidelines and more frequent inspections of correct use and heating of water (fountains, showers, cooling) (VROM 2004). EHR governance in addition is criticised for not being effective; too much money would go to EHRs that could be reduced only at high costs or management instruments are chosen that are too costly (for comparative cost-effectiveness evaluations of US risk reduction policies, see Tengs et al. 1995; for Japan, Kishimoto, Oka, and Nakanishi 2003; for the Netherlands, NEAA 2009).

\subsubsection{Problem 3: A discrepancy between scientific and public or stakeholder} perceptions. In some cases the public or stakeholders and scientists have different perceptions of the severity of health risks, which results in an active regulation of EHRs for which there is no science-based reason for concern. In the Netherlands, for instance, millions of euros were made available for research on health effects of radiation from mobile phone transmitting stations in response to public concerns, while there was little scientific evidence of realness of perceived effects. This illustrates another important shortcoming of the specialised approach: difficulties in reconciling 'objective' scientific EHR assessments and 'subjective' EHR perceptions by the public. Perceptions of stakeholders are considered to have become more important due to scientific limitations, trust and democracy concerns and a growing dependence of governments on stakeholders. Even though knowledge has been built on variables that affect the perceived seriousness of risks (e.g. voluntariness and personal control, the catastrophic potential, emotional associations with the risk, trust in regulatory agencies (Flynn, Slovic, and Mertz 1994; Starr 1969) and the availability of guidelines for taking public perceptions of EHRs explicitly into account (e.g. Klinke and Renn 2002)), this issue has thus far only been addressed marginally in EHR governance regimes (e.g. in the Netherlands and elsewhere for external safety a distinction is made between 'individual risk' and 'group risk' based on the societal impact of a group of people killed or injured in comparison to individual casualties). An overall framework for incorporating public concerns in EHR governance has only been theoretically developed but not very much applied in participative risk management processes. This particularly applies to standard-setting: when does an 'objective' risk standard (based on scientific risk calculations) suffice and when is an EHR standard that is based more on public perceptions and perceived reasons for concern adequate (NEAA 2009)?

\subsubsection{Problem 4: A lack of incentives to reduce EHRs beyond legal norms.} Compliance with current EHR standards or setting of even stricter, more health protective EHR standards is often hindered by conflicts between EHR reduction objectives (exceedance or compliance of standards may at times not give a clear indication of reaching a non-healthy or healthy condition) and those of other policy 
domains, in particular economic progress and spatial planning (NEAA 2009). In particular in intensively used urban areas, further spatial developments are often hindered by strict EHR norms (Glasbergen 2005; NEAA 2009; Wheeler and Beatley 2004). In 2008 air quality standards for ambient particulate matter and $\mathrm{NO}_{2}$ were still not met at several locations in The Netherlands and the existing policies are not likely to meet the 2010 standard in time (NEAA 2008). The institutional context that puts responsibilities for EHR governance mainly on state agencies (that, in addition, often prescribe detailed (minimum) standards for EHRs) does not provide an incentive for actors involved (manufacturers, planners, etc.) to reduce EHRs beyond the legal minimum standards or to find innovative ways for reducing EHRs either (Health Council of the Netherlands 1995).

3.1.3.5. Problem 5: Inadequate management of health risks beyond the level of individual EHRs. A fifth problem with the specialised approach relates to difficulties in dealing with 'cumulative' effects of EHRs associated with multiple (simultaneous) exposures (e.g. Callahan and Sexton 2007; Health Council of the Netherlands 1995; US EPA 2004). For instance, the 2003 heat wave in Western Europe coincided with high ambient ozone levels in urban areas, leading to unanticipated magnitude of the effects co-produced by heat stress and peak levels in troposphere ozone in the Netherlands and in many French cities (Filleul et al. 2006; Fischer, Brunekreef, and Lebret 2004). On the one hand, such effects are overlooked in the case of (single) source-based regulations (in contrast to effect-based regulations, such as the EU Directives for air pollution that prescribe maximum concentrations of, for instance, particulate matter). On the other hand, problems exist because of a lack of knowledge of the combined effect of various environmental exposures and associated EHRs (e.g. Robinson and MacDonell 2006; VROM 2004). Apart from that, the specialised approach sometimes results in 'risk migration' (see Section 2.3).

\subsubsection{Problem 6: Obscurity about responsibilities for EHR governance. A sixth} problem with traditional EHR governance regimes is that it is not always clear which societal actor should take responsibility for dealing with EHRs, in particular when those causing risks or in control of instruments for reducing EHRs can be distinguished clearly or when governments are expected to deregulate (Renn 2006; UK HM Treasury 2005; VROM 2004). Examples include exposure to electro magnetic fields from antitheft portals in shops and residuals from medicines that appear in the environment up to now no actor has taken the responsibility to monitor or tackle these problems.

In sum, different sorts of risks seem incomparable, thus calling for more differentiated approaches to EHRs.

\section{2. 'Integrated' and 'differentiated' EHR governance regimes}

\subsubsection{Characterising new EHR governance regimes}

A recent survey of trends in EHR governance in 10 European countries, the USA and Australia (Soer et al. 2009) revealed various changes in EHR governance regimes. It should be noted that these trends are not found in all of these countries in the same intensity. Nevertheless the study points to the following changes in the elements of EHR governance regimes outlined in our framework (see Figure 3): 
- Regarding EHR objectives: an increased differentiation can be discerned. In the Netherlands, for instance, some experiments have been conducted with providing urban planners more policy freedom in the formulation of area-specific environmental ambitions (Runhaar, Driessen, and Soer 2009). In this way a better coordination and local optimisation of environmental (health) planning and spatial planning is facilitated. These experiments allow for a limited form of differentiation of environmental objectives (in a spatial sense). Compensation a lower environmental quality in one domain being offset by an improvement in another - was also envisaged, but appeared impossible (also in the light of EU Directives). Also in Scotland it is legally possible to generate area-specific environmental standards (Soer et al. 2009). Also at a national level norm differentiation can be observed. In the Netherlands, for example, EHR planners have differentiated norms for soil quality according to land use functions. Soil norms for houses are stricter than for those for industrial areas. The same approach has been followed as regards noise nuisance risks (Glasbergen 2005). Obviously differentiation of EHR standards is not a new phenomenon - however, in the past differentiation usually related only to predefined situations. Differentiation is also envisaged in another form - an explicit and deliberate (rather than an ad hoc) differentiation of EHR governance regimes for distinct types of EHRs in terms of stakeholder involvement, division of responsibilities, etc. Up to now several countries, including the Netherlands, Malta and the United Kingdom, have decided to adopt such an approach (Soer et al. 2009). Yet implementation is still in an early stage. It is therefore still uncertain whether or not this type of differentiation is feasible, realistic or even desirable. Differentiation follows from a more explicit and earlier (and perhaps also more intensive) consideration of cost-benefit, public, economic and other concerns in EHR assessments (e.g. UK HM Treasury 2005; NEAA 2009; VROM 2004). In certain situations this has gone at the expense of the principle of 'equal protection for all', often taken as a principle in the classical risk management approach. Incorporation of costbenefit and other concerns among other things is aimed at better integrating EHR standard-setting and EHR implementation. There are, however, also countries that explicitly do not consider costs or feasibility in the risk assessment and standard-setting stage (e.g. Australia and the USA; Soer et al. 2009).

- Regarding knowledge sources: a few efforts have been made to reconcile scientific and stakeholder risk perceptions. The UK HM Treasury (2005), for instance, has proposed to make 'concern assessment' an integral part of risk management. Since 2006 there is a legislative requirement to attempt incorporating public opinion in the decision-making process by means of such an assessment, although it is recognised that 'public attitudes to risk are difficult to measure'; and that 'public concerns may be founded on ignorance, false information, unreliable media reporting, etc.' (UK House of Lords 2006, 6). Eventually it is up to decisionmakers to determine the relative weight of such factors.

- Regarding management instruments: risk assessment and management are more integrated. Also, EHR objectives are increasingly integrated in other sectors, in particular in spatial planning. Examples of countries are Australia, Germany and the Netherlands. Regularly used tools for better incorporating EHRs in spatial planning are 'Health Effect Screenings', 'Health Impact Assessments' and 'Strategic Environmental Assessments'. In Malta integration between policy sectors is strived for through the formation of an inter-departmental committee 
on environment and health (Soer et al. 2009). Finally, in countries such as the UK and the Netherlands, a shift can be discerned from detailed prescriptions of EHR standards and the ways in which these have to be met, to regulations that concentrate on objectives regarding risk reduction. This is related to the desire of governments to make stakeholders co-responsible for EHR governance but also to allow for tailor-made (and hence more efficient and (cost-)effective) EHR management (NEAA 2009).

- Regarding actors: the public and other stakeholders are increasingly involved in the formulation and implementation of EHR governance regimes. Not only is a more participatory approach to EHRs increasingly considered necessary in order to create support for EHR policies, it also stems from a desire to make other stakeholders co-responsible for preventing and reducing EHRs (Renn 2006; Soer et al. 2009; UK HM Treasury 2005; VROM 2004). Participation sometimes serves to create legitimacy and trust, for instance in the UK where public protest arose after the public was exposed to 'unacceptable' risks relating to, among other things, BSE (Fisher 2000).

At a more meta-level, these trends reflect a change to more integration (of costbenefit and other considerations in EHR policy and standard-setting; of stakeholders in the formulation and implementation of EHR governance regimes; and of EHR objectives in other policy sectors) and more differentiation of EHR policy and standard-setting (partly as a consequence of the former shifts).

The above shifts can be considered as ways to overcome the limitations of the classical risk management strategy and of the outcomes of more 'specialised' regimes. However, part of the shifts can also be explained by more general developments in the broader societal context. The trend towards more public and stakeholder participation and integration of policy sectors form part of a broader shift towards more integrated approaches to dealing with societal issues in Western, liberal societies, which are commonly referred to a change in planning from 'government' to 'governance' (NEAA 2009). There is no agreed-upon definition of what governance entails (Jordan, Wurzel, and Zito 2005). Yet, often-mentioned characteristics are: a decline of central government's ability to regulate society in a top-down fashion, resulting in more horizontal forms of steering in cooperation with other government ties and stakeholders outside the government; a more direct and early inclusion of stakeholders in the formulation and implementation of policies; shared responsibilities between state, civil society and market actors in the formulation and implementation of policies; (as a consequence) a blurring of the traditional boundaries between state, civil society and market (Driessen and Glasbergen 2002; van Kersbergen and van Waarden 2001).

\subsubsection{More 'integrated' and 'differentiated' EHR regimes: outcomes and challenges ahead}

The shift towards more integration and differentiation is observed in several countries but is far from crystallised. In many of the countries examined, plans are in immature stages or even only under consideration. Not much experience has been built with increased integration and differentiation in EHR policies. Yet a few new dilemmas were identified, including the weighing of stakeholder opinions and scientific inputs and the weighing of health and other concerns (see also Glasbergen 2005, and Runhaar, Driessen, and Soer 2009). In addition EHR planners state that they lack a clear and 
practical framework for systematically dealing with EHRs. 'Old' problems that are not solved in more integrated and differentiated EHR governance regimes include a lack of (scientific) data (e.g. on cumulative and risk migration effects), insufficient funding and problems in communication between EHR planners, other sectoral planners and stakeholders. Finally a potential risk of more integration is compromising of EHR standards in favour of other ambitions (Soer et al. 2009).

It is far from certain that more integrated and differentiated governance regimes will completely replace more traditional EHR regimes. In Europe, EHRs are increasingly targeted at a supranational level (EU) by means of Directives that prescribe strict and uniform standards for acceptable EHRs (albeit these often also incorporate costbenefit considerations). It is interesting to examine how these various forms of EHR regimes interact.

\section{Conclusions}

Although governance regimes for EHRs are rather heterogeneous, at a meta-level some trends can be discerned that point to a convergence of EHR governance. Given the limited attention being paid to EHR governance regimes in empirical risk research, in this paper we first developed an analytical framework for characterising, explaining and evaluating such EHR regimes and their outcomes, based on a review of relevant literature. Then we discussed and evaluated some meta-level trends we observed in a sample of Western countries.

The framework seems to be useful for guiding research into the above area as it allows for a systematic examination of relevant elements and possible relationships. We recommend it for the analysis and evaluation of EHR governance regimes and for analysing shifts in EHR governance. In the analysis of recent shifts in EHR governance we discussed as an illustration of our framework, not all of the elements were elaborated on in much detail. Cultural influences on governance regimes, for instance, may be identified more explicitly in an international comparative study.

We suggest that further research is conducted in order to classify EHR governance regimes with the aid of our framework. What distinct configurations can be found in practice, next to the (perhaps artificially constructed) 'specialised' approach we discussed? The shifts towards more integration and differentiation identified in the survey conducted by Soer et al. (2009) may act as a starting point. Three remarks should be made here. One, in this study only a (probably non-representative) sample of countries was included. Two, the shifts identified were not observed in each of the sample countries in the same intensity. Three, the survey focused on the main characteristics of national EHR governance regimes; no in-depth research was conducted into specific EHRs. However, many of the trends that we observed are similar to those reported by, for instance, Amendola (2001), De Marchi (2003), Heriard-Dubreuil (2001) and Rothstein et al. (2006).

\section{Notes}

1. In this context, Klinke and Renn speak of 'ambiguity': the presence of 'contested views about the desirability or severity of a given hazard' (Klinke and Renn 2002, 1092).

2. In the Netherlands but also abroad there are various events that were followed by changes in EHR governance; for example, the 1977 dioxin incident in Seveso, Italy, the 1980/1981 soil pollution 'scandal' in Lekkerkerk, the 2000 fireworks accident in Enschede and the near floods in 1993/1995 (water safety) (NEAA 2009; Wiering and Arts 2006). 


\section{References}

Alcock, R.E., and J. Busby. 2006. Risk migration and scientific advance: The case of flameretardant compounds. Risk Analysis 26, no. 2: 369-81.

Amendola, A. 2001. Recent paradigms for risk informed decision making. Safety Science 40, no. $1-4: 17-30$.

Annesi-Maesano, I., F. Forastiere, N. Kunzli, and B. Brunekreef. 2007. Particulate matter, science and EU policy (editorial). European Respiratory Journal 29, no. 3: 428-31.

Bunting, C. 2008. An introduction to the IRGC's risk governance framework. Paper presented at the 2nd RISKBASE General Assembly and 2nd Thematic Workshop WP1b, May 15-17, in Budapest, Hungary.

Callahan, M.A., and K. Sexton. 2007. If cumulative risk assessment is the answer, what is the question? Environmental Health Perspectives 115, no. 5: 799-806.

De Hollander, A., and A. Hanemaaijer. 2003. Nuchter omgaan met risico's [Dealing sensibly with risks]. Bilthoven: Netherlands Environmental Assessment Agency. (in Dutch)

De Marchi, B. 2003. Public participation and risk governance. Science and Public Policy 30, no. 3: 171-6.

Driessen, P.P.J., and P. Glasbergen. 2002. New directions in environmental politics: Concluding remarks. In Greening society: The paradigm shift in Dutch environmental politics, ed. P.P.J. Driessen and P. Glasbergen, 245-62. Dordrecht: Kluwer.

EEA. 2003. Europe's water: An indicator-based assessment. Copenhagen: European Environmental Agency.

- 2007. Air pollution in Europe 1990-2004. Copenhagen: European Environmental Agency.

Filleul, L., S. Cassadou, S. Médina, P. Fabres, A. Lefranc, D. Eilstein, A. Le Tertre, et al. 2006. The relation between temperature, ozone, and mortality in nine French cities during the heat wave of 2003. Environmental Health Perspective 114, no. 9: 1344-7.

Fiorino, D.J. 1990. Citizen participation and environmental risk: A survey of institutional mechanisms. Science, Technology \& Human Values 15, no. 2: 226-43.

Fischer, F. 1997. Evaluating public policy. Chicago: Nelson-Hall.

Fischer, P., B. Brunekreef, and E. Lebret. 2004. Air pollution related deaths during the 2003 heat wave in the Netherlands. Atmospheric Environment 38, no. 8: 1083-5.

Fisher, E. 2000. Drowning by numbers: Standard setting in risk regulation and the pursuit of accountable public administration. Oxford Journal of Legal Studies 20, no. 1: 109-30.

Flynn, J., P. Slovic, and C.K. Mertz. 1994. Gender, race, and perception of environmental health risks. Risk Analysis 14, no. 6: 1101-8.

Glasbergen, P. 2005. Decentralized reflexive environmental regulation: Opportunities and risks based on an evaluation of Dutch experiments. Environmental Sciences 2, no. 4: 427-42.

Handy, R.D., R. Owen, and E. Valsami-Jones. 2008. The ecotoxicology of nanoparticles and nanomaterials: Current status, knowledge gaps, challenges, and future needs. Ecotoxicology 17, no. 5: 315-25.

Harrami, O., U. Postgård, and M. Strömgren. 2009a. Evaluation of risk and safety issues at the Swedish Rescue Services Agency. In Safety, reliability and risk analysis: Theory, methods and applications, ed. S. Martorell, C. Guedes Soares, and J. Barnett, 399-406. London: CRC Press.

Harrami, O., M. Strömgren, U. Postgård, and R. All. 2009b. Accidents, risk analysis and safety management: Different perspective at a Swedish safety agency. In Safety, reliability and risk analysis: Theory, methods and applications, ed. S. Martorell, C. Guedes Soares, and J. Barnett, 391-8. London: CRC Press.

Health Council of the Netherlands. 1995. Niet alle risico's zijn gelijk: kanttekeningen bij de grondslag van de risicobenadering in het milieubeleid [Not all risks are equal: A critical approach to environmental health risk policy]. The Hague: Gezondheidsraad. (in Dutch)

Heriard-Dubreuil, G.F. 2001. Present challenges to risk governance. Journal of Hazardous Materials 86, no. 13: 245-8.

Hood, C., H. Rothstein, and R. Baldwin. 2004. The government of risk. Oxford: Oxford University Press.

Johnson, C.L., S.M. Tunstall, and E.C. Penning-Rowsell. 2005. Floods as catalysts for policy change: Historical lessons from England and Wales. Water Resources Management 21, no. 4: 561-75. 
Jordan, A., R.K.W. Wurzel, and A. Zito. 2005. The rise of 'new' policy instruments in comparative perspective: Has governance eclipsed government? Political Studies 53, no. 3: 477-96.

Keijzers, G. 2000. The evolution of Dutch environmental policy: The changing ecological arena from 1970-2000 and beyond. Journal of Cleaner Production 8, no. 3: 179-200.

Kishimoto, A., T. Oka, and J. Nakanishi. 2003. The cost-effectiveness of life-saving interventions in Japan: Do chemical regulations cost too much? Chemosphere 53, no. 4: 291-9.

Klinke, A., and O. Renn. 2002. A new approach to risk evaluation and management: Riskbased, precaution-based, and discourse-based strategies. Risk Analysis 22, no. 6: 1071-94.

Langford, I.H., S. Georgiou, I.J. Bateman, R.J. Day, and R.K. Turner. 2000. Public perceptions of health risks from polluted coastal bathing waters: A mixed methodological analysis using cultural theory. Risk Analysis 20, no. 5: 691-704.

Loewenberg, S. 2006. US chemical companies leave their mark on EU law. Lancet 367, no. 9510: 556-7.

Mack, R.N., D. Simberloff, W.M. Lonsdale, H. Evans, M. Clout, and F. Bazzaz. 2000. Biotic invasions: Causes, epidemiology, global consequences and control. Issues in Ecology 5, no. 3: 1-19.

McMichael, A.J., and R. Beaglehole. 2000. The changing global context of public health. Lancet 356, no. 9228: 495-9.

NEAA. 2008. Milieubalans [Environmental fact sheet]. Bilthoven: Netherlands Environmental Assessment Agency. (in Dutch)

-2009. Nuchter omgaan met risico's II. Een vergelijkende studie naar het Nederlandse risicobeleid [Dealing sensibly with risks II: A comparative analysis of Dutch risk policies]. Bilthoven: Netherlands Environmental Assessment Agency. (in Dutch)

Neumann, P., and R. Politser. 1992. Risk and optimality. In Risk-taking behaviour, ed. F. Yates, 27-47. Chichester: Wiley.

Open University. 1998. Risico's: besluitvorming over veiligheid en milieu [Risks: Decisionmaking on safety and the environment]. Heerlen: Open University. (in Dutch; course book)

O'Riordan, T. 1985. Approaches to regulation. In Regulating industrial risks: Science, hazards and public protection, ed. H. Otway and M. Peltu, 20-39. London: Butterworth.

Rayner, S., and R. Cantor. 1987. How fair is safe enough? The cultural approach to societal technology choice. Risk Analysis 7, no. 1: 3-9.

Renn, O. 2006. Risk governance: Towards an integrative approach. Geneva: International Risk Governance Council.

- 2008a. Concepts of risk: An interdisciplinary review - Part 1. Disciplinary risk concepts. GAIA 17, no. 1: 50-77.

- 2008b. Introduction. In Global risk governance: Concept and practice using the IRGC framework, ed. O. Renn and K. Walker, 3-73. Dordrecht: Springer.

2008c. Risk governance: Coping with uncertainty in a complex world. London/ Sterling: Earthscan.

Robinson, P., and M. MacDonell. 2006. Priorities for mixtures health effects research. Environmental Toxicology and Pharmacology 18, no. 3: 201-13.

Rothstein, H., P. Irving, T. Walden, and R. Yearsley. 2006. The risks of risk-based regulation: Insights from the environmental policy domain. Environment International 32, no. 8: $1056-65$.

Runhaar, H.A.C., P.P.J. Driessen, and L. Soer. 2009. Sustainable urban development and the challenge of policy integration: An assessment of planning tools for integrating spatial and environmental planning in the Netherlands. Environment and Planning B 36, no. 3 : 417-31.

Soer, L., L. van Bree, P.P.J. Driessen, and H. Runhaar. 2009. Towards integration and differentiation in environmental health-risk policy approaches: An international quick-scan of various national approaches to environmental health risk. Utrecht/Bilthoven: Copernicus Institute for Sustainable Development and Innovation/Netherlands Environmental Assessment Agency (http://igitur-archive.library.uu.nl/milieu/2009-0305-202412/UUindex.html).

Starr, C. 1969. Social benefit versus technological risk: What is our society willing to pay for safety? Science 165: 1232-8.

Stohlgren, T.J., and J.L. Schnase. 2006. Risk analysis for biological hazards: What we need to know about invasive species. Risk Analysis 26, no. 1: 163-73. 
Sunstein, C.R. 2002. Risk and reason: Safety, law, and the environment. New York: Cambridge University Press.

Tengs, T.O., M.E. Adams, J.S. Pliskin, D.G. Safran, J.E. Siegel, M. Weinstein, and J.D. Graham. 1995. Five hundred life-saving interventions and their cost-effectiveness. Risk Analysis 15, no. 3: 369-90.

Tukker, A. 2002. Risk analysis, life cycle assessment: The common challenge of dealing with the precautionary frame (based on the toxicity controversy in Sweden and the Netherlands). Risk Analysis 22, no. 5: 821-32.

UK HM Treasury. 2005. Managing risk to the public: Appraisal guidance. London: HM Treasury.

UK House of Lords. 2006. Economic affairs -fifth report. London: House of Lords.

US EPA. 2004. Risk assessment principles and practices. Washington, DC: United States Environmental Protection Agency.

Valberg, P.A., E. van Deventer, and M.H. Repacholi. 2007. Workgroup report: Base stations and wireless networks - Radiofrequency (RF) exposures and health consequences. Environmental Health Perspectives 115, no. 3: 416-24.

van de Riet, O. 2003. Policy analysis in multi-actor policy settings: Navigating between negotiated nonsense and superfluous knowledge. PhD diss., Delft University of Technology.

van Kersbergen, K., and F. van Waarden. 2001. Shifts in governance: Problems of legitimacy and accountability. The Hague: Social Science Research Council.

Vos, P.D., W.D. Ceukelaire, and P.V.D. Stuyft. 2006. Colombia and Cuba: Contrasting models in Latin America's health sector reform. Tropical Medicine and International Health 11, no. 10: 1604-12.

VROM. 2004. Nuchter omgaan met risico's. Beslissen met gevoel voor onzekerheden [Dealing sensibly with risks]. The Hague: Department of Housing, Spatial Planning, and the Environment. (in Dutch)

Wheeler, S.M., and T. Beatley, eds. 2004. The sustainable urban development reader. London/New York: Routledge.

Wiering, M.A., and B.J.M. Arts. 2006. Discursive shifts in Dutch river management: 'Deep' institutional change or adaptation strategy? Hydrobiologia 565, no. 1: 327-38. 